\title{
Laccase mediated delignification of pineapple leaf waste: an ecofriendly sustainable attempt towards valorization
}

\author{
Rintu Banerjee ${ }^{1 *}$, Anjani Devi Chintagunta ${ }^{2}$ and Subhabrata Ray ${ }^{3}$
}

\begin{abstract}
Background: Escalating energy security, burgeoning population and rising costs of fossil fuels have focussed our attention on tapping renewable energy sources. As the utilization of food crops for biofuel production culminates into food vs. fuel dilemma, there is an intensive need for alternatives. Production of biofuels from lignocellulosic biomass owing to its profuse availability and high holocellulose content is a promising area for research.

Results: In the present study, pineapple leaf, an agro-industrial waste was pretreated with laccase to enhance the enzymatic digestibility of the substrate for improved production of reducing sugar. Variables determining enzymatic delignification of pineapple leaf waste have been optimized by response surface methodology based on central composite design. Maximum delignification of $78.57 \%(\mathrm{w} / \mathrm{w})$ resulted in reducing sugar of $492.33 \pm 3.1 \mathrm{mg} / \mathrm{g}$ in $5.30 \mathrm{~h}$. The structural changes in pineapple leaf waste, after laccase treatment, were studied through Fourier transformed infrared spectroscopy, X-ray diffraction and Scanning electron microscopy. Specific surface area, pore volume, and pore diameter of the substrate were studied using the Brunauer-Emmett-Teller and Barrett-Joyner-Halenda methods and found a significant increase in the aforementioned parameters after delignification.
\end{abstract}

Conclusion: Laccase mediated delignification of pineapple leaf waste is a cleaner sustainable process for enhanced production of reducing sugar which can accomplish the demand for biofuels.

Keywords: Cellulose, Enzymatic pretreatment, Laccase, Pineapple leaf waste

\section{Introduction}

Lignocellulosic biomass is a potential renewable resource for biofuel production due to wide availability, low cost and rich holocellulose content. Predominant lignocellulosics that have been employed for bioenergy production are oil palm frond [1], poplar [2], switch grass [3] and barley straw [4]. In addition to these feedstocks, pineapple waste is another prominent lignocellulosics, which is being produced abundantly by canning industries throughout the world. The worldwide pineapple production was estimated to be $24.80 \mathrm{Mt}$ from 1.02 Mha for the year 2013-2014 [5] the production from India being 1.74 Mt from 0.11 Mha [6]. A major share of the

\footnotetext{
*Correspondence: rb@iitkgp.ac.in

${ }^{1}$ Agricultural \& Food Engineering Department, Indian Institute

of Technology, Kharagpur, West Bengal 721302, India

Full list of author information is available at the end of the article
}

total production is processed in canneries resulting in generation of substantial amount of waste comprising the peel, crown, leaves etc. The peel and stems of pineapple waste is employed for the production of valuable products like bromelain and vinegar [7]. A part of leaf waste is used in making rope fibres and paper industries. Being rich in reducing sugar and holocellulosic content (65$67 \%, w / w)$, pineapple leaf waste has a great potential for bioethanol production.

A major impediment in the utilization of lignocellulosic biomass as a substrate for ethanol production is the presence of lignin that resists chemical or enzymatic digestion of cellulose and hemicellulose polymers [8]. Lignin and hemicelluloses form a barrier around the crystalline and amorphous regions of cellulose. Hence, the breakdown of lignin is essential for accessing the cellulose component of the lignocellulosics, 
which requires an appropriate pretreatment process. Among the various methods of pretreatment like physical, chemical, physicochemical and biological, enzymatic pretreatment or delignification process is beneficial owing to its high specificity, low energy requirements, higher yield of reducing sugar and minimum by-product formation.

The mechanism involved in various pretreatment processes specifically pertaining to the alterations in physical structure and chemical composition of biomass should be understood completely. The ultimate goal of any pretreatment process is to enhance the accessibility of biomass to the enzymes for efficient generation of reducing sugar at low enzyme dose. The conventional pretreatment methods result in the formation of furfurals, hydroxymethyl furfurals, acetic acid and formic acid etc., that inhibit the subsequent steps of bioethanol production. During enzymatic delignification, enzyme acts specifically and release phenolic intermediates which act as natural mediators enhancing the delignification process [9]. High yield of reducing sugar was reported during saccharification after chemical pretreatment of Kans grass [10]. It was reported that enzymatically delignified lignocellulosics yielded high reducing sugar content after saccharification when compared to that treated with steam explosion and acid pretreatments $[11,12]$.

Owing to the aforementioned advantages of enzymatic pretreatment, laccase mediated delignification of pineapple leaf waste was carried out in the present study. Laccase is an extracellular, multi-copper enzyme which degrades lignin through molecular oxygen and oxidizes different aromatic and non-aromatic compounds present in lignin [13]. Till date, very few reports are available on the enzymatic pretreatment of different lignocellulosics and its effect on reducing sugar production $[14,15]$.

Recently, multivariate statistical techniques are predominantly being used for optimization of process parameters. Factorial designs viz., central composite and Box-Behnken are used, for evaluating the effect of one factor at several levels of other factors in addition to the interaction among them, which is not possible in one-factor-at-a-time [16]. In the present work, optimization of enzymatic pretreatment of pineapple leaf waste was carried out by response surface methodology (RSM) based on central composite design (CCD). It is worth mentioning that decrease in lignin and hemicellulose content due to pretreatment process affects the physical properties of the cellulosic component such as crystallinity, surface area of the substrate etc. Structural characterization was done to corroborate the delignification process and porosity measurements to assess the accessible surface area of the substrate to cellulase for reducing sugar production. Enzymatic delignification is a green, sustainable and eco-friendly approach for production of biofuel and other bio-products.

\section{Methods}

Substrate and its biochemical characterisation

Pineapple (Ananas comosus, Giant Kew variety) leaf waste was collected locally from the farm of IIT Kharagpur, India. It was chopped, sun dried, pulverised to particle size of $0.2 \mathrm{~mm}$ and used in the present study. Lignin, cellulose and hemicellulose content of raw and delignified pineapple leaf wastes were estimated using standard protocols [17-19]. The amount of reducing sugar was measured by dinitrosalicylic acid method (DNS) [20]. The elemental analysis of moisture free raw and delignified pineapple leaf waste was done by the CHNS analyser (M/s Elementar, VarioMicrocube, Germany).

\section{Enzyme}

Enzymatic delignification of the substrate was done using laccase from Pleurotus djamor. Enzyme activity was determined spectrophotometrically using $2,2^{\prime}$-azino-bis (3-ethylbenzothiazoline-6-sulphonic acid) (ABTS) as substrate [21]. The activity of laccase was represented in international unit (IU) which is defined as the amount of enzyme required to oxidize $1 \mu \mathrm{mol}$ of ABTS per minute under the assay conditions.

\section{Optimization of enzymatic delignification of pineapple leaf waste}

Parameters like solid loading (5-40\% w/v), enzyme concentration (100-1000 IU/mL), incubation time (2-12 h), temperature $\left(30-60{ }^{\circ} \mathrm{C}\right)$ and $\mathrm{pH}(3-10)$ were selected to study their effect on enzymatic delignification process and further optimization was done by RSM based on CCD. After delignification process, the solid residue was washed, dried and used for estimation of residual lignin and percentage delignification.

$$
\begin{aligned}
\% \text { Delignification }= & \frac{\text { Initial lignin }- \text { Final lignin }}{\text { Initial lignin }} \\
& \times 100 \times \text { solid recovery fraction. }
\end{aligned}
$$

Optimization and evaluation of enzymatic delignification of pineapple leaf waste was carried out using threelevel, $2^{5}$ full factorial CCD with five process parameters. The boundary parameters studied in the process of enzymatic delignification were solid loading $(15-25 \% \mathrm{w} / \mathrm{v})$, incubation time $(5-7 \mathrm{~h}), 35-45^{\circ} \mathrm{C}, \mathrm{pH}(6-8)$ and enzyme concentration (300-700 IU/mL). The experimental design and analysis of data were done using MINITAB 16 software. The designed experimental runs were tabulated in uncoded terms $-1,0,+1$ as lowest, middle and highest level of five variables respectively in Table 1 . The 
Table 1 Experimental design for enzymatic delignification of pineapple leaf waste in terms of uncoded level of variables based on central composite design

\begin{tabular}{|c|c|c|c|c|c|c|c|}
\hline \multirow[t]{2}{*}{ Run order } & \multirow{2}{*}{$\begin{array}{l}\text { Solid loading (\% } \\
\text { w/v) }\end{array}$} & \multirow{2}{*}{$\begin{array}{l}\text { Incubation time } \\
\text { (h) }\end{array}$} & \multirow[t]{2}{*}{ Temperature $\left({ }^{\circ} \mathrm{C}\right)$} & \multirow[t]{2}{*}{$\mathrm{pH}$} & \multirow{2}{*}{$\begin{array}{l}\text { Enzyme } \\
\text { concentration (IU/ } \\
\mathrm{mL} \text { ) }\end{array}$} & \multicolumn{2}{|c|}{ Delignification (\%) } \\
\hline & & & & & & Experimental & Predicted \\
\hline 1 & 20 & 6 & 40 & 7 & 500 & 69.91 & 70.53 \\
\hline 2 & 20 & 6 & 40 & 7 & 500 & 68.56 & 70.53 \\
\hline 3 & 15 & 6 & 40 & 7 & 500 & 71.92 & 73.44 \\
\hline 4 & 25 & 7 & 45 & 8 & 700 & 69.30 & 69.53 \\
\hline 5 & 15 & 7 & 45 & 6 & 700 & 71.24 & 71.00 \\
\hline 6 & 20 & 6 & 40 & 8 & 500 & 68.90 & 68.52 \\
\hline 7 & 15 & 5 & 45 & 6 & 300 & 70.41 & 70.40 \\
\hline 8 & 15 & 7 & 45 & 8 & 300 & 62.21 & 62.29 \\
\hline 9 & 20 & 6 & 45 & 7 & 500 & 73.52 & 72.64 \\
\hline 10 & 25 & 7 & 35 & 6 & 700 & 66.79 & 67.12 \\
\hline 11 & 15 & 7 & 35 & 8 & 700 & 57.89 & 57.52 \\
\hline 12 & 25 & 5 & 45 & 8 & 300 & 58.81 & 59.27 \\
\hline 13 & 25 & 5 & 45 & 6 & 700 & 67.56 & 67.70 \\
\hline 14 & 25 & 7 & 35 & 8 & 300 & 56.33 & 56.99 \\
\hline 15 & 20 & 6 & 40 & 7 & 500 & 70.79 & 70.53 \\
\hline 16 & 15 & 5 & 45 & 8 & 700 & 64.13 & 63.57 \\
\hline 17 & 20 & 6 & 40 & 7 & 300 & 65.52 & 62.93 \\
\hline 18 & 15 & 7 & 35 & 6 & 300 & 50.87 & 51.05 \\
\hline 19 & 20 & 6 & 40 & 7 & 700 & 67.52 & 68.44 \\
\hline 20 & 20 & 6 & 40 & 7 & 500 & 70.49 & 70.53 \\
\hline 21 & 20 & 7 & 40 & 7 & 500 & 68.45 & 66.80 \\
\hline 22 & 25 & 7 & 45 & 6 & 300 & 64.33 & 65.11 \\
\hline 23 & 20 & 6 & 40 & 7 & 500 & 68.23 & 70.53 \\
\hline 24 & 25 & 6 & 40 & 7 & 500 & 78.14 & 74.96 \\
\hline 25 & 15 & 5 & 35 & 8 & 300 & 57.89 & 57.76 \\
\hline 26 & 20 & 5 & 40 & 7 & 500 & 66.15 & 66.13 \\
\hline 27 & 25 & 5 & 35 & 6 & 300 & 52.43 & 53.00 \\
\hline 28 & 15 & 5 & 35 & 6 & 700 & 58.69 & 58.23 \\
\hline 29 & 20 & 6 & 35 & 7 & 500 & 65.69 & 64.90 \\
\hline 30 & 25 & 5 & 35 & 8 & 700 & 65.25 & 65.26 \\
\hline 31 & 20 & 6 & 40 & 7 & 500 & 68.53 & 70.53 \\
\hline 32 & 20 & 6 & 40 & 6 & 500 & 71.24 & 69.95 \\
\hline
\end{tabular}

effect of independent factors and their interactions on $\%$ delignification was represented as polynomial quadratic regression equation. The interactive effects among various parameters was analysed based on 3D response surface plots.

\section{Energy density measurement}

The energy density of the raw and delignified pineapple leaf waste was measured using Bomb Calorimeter (Oxygen Bomb Calorimeter, Eastern Instruments, Kolkata, India). The samples were dried at $60{ }^{\circ} \mathrm{C}$ in an oven for removing the moisture and then formed into pellets. The heat content of the samples was determined in the presence of excess oxygen and high pressure $\left(2.75 \times 10^{6} \mathrm{~Pa}\right)$. The energy density $(\mathrm{kJ} / \mathrm{g})$ of the solid samples were determined as following:

$$
\text { Energy density }(\mathrm{kJ} / \mathrm{g})=\frac{W \times\left(T_{2}-T_{1}\right)}{M}
$$

where $\mathrm{W}$ is the water equivalent of calorimeter $\left(9.748 \mathrm{~kJ} /{ }^{\circ} \mathrm{C}\right), \mathrm{M}$ is the mass of the sample and $\left(\mathrm{T}_{2}-\mathrm{T}_{1}\right)$ is the rise in the temperature.

\section{Structural characterization}

The morphological studies of raw and delignified pineapple leaf waste were carried out by scanning electron 
microscopy (SEM). The dried samples were mounted on a stub of metal with adhesive, coated with gold and viewed under JEOL JSM 5800 SEM (Jeol Ltd., Tokyo, Japan).

Fourier transform infrared spectroscopy (FTIR) was carried out for both raw and delignified samples of pineapple leaf waste using $\mathrm{KBr}$ pellet technique in spectral range of $400-4000 \mathrm{~cm}^{-1}$ with a resolution of $0.5 \mathrm{~cm}^{-1}$. The FTIR analysis was mainly intended to study the functional groups available in lignocellulosic substrate and changes in intensity of absorption bands due to enzymatic action.

The crystallinity of raw and delignified samples of pineapple leaf waste was determined through $\mathrm{X}$-ray diffraction (XRD) studies using $\mathrm{CoK} \alpha$ radiation $(\alpha=1.79 \AA)$ at $20 \mathrm{~mA}$ and $40 \mathrm{kV}$. The samples were scanned from $2 \theta=15^{\circ}$ to $75^{\circ}$ with a speed of $3^{\circ} \%$ min. The percentage crystallinity was calculated from $\left[\left(I_{002}-I_{\mathrm{am}}\right) / I_{002}\right] \times 100$, where $I_{002}$ represents maximum peak intensity $(2 \theta)$ between $22^{\circ}$ and $23^{\circ}$ and $I_{\text {am }}$ represents minimum peak intensity $(2 \theta)$ between $18^{\circ}$ and $19^{\circ}$ for cellulose $I$ [22].

\section{Porosity analysis}

Specific surface area, pore volume and pore diameter of pineapple leaf waste sample were studied using the Brunauer-Emmett-Teller (BET) and Barrett-JoynerHalenda (BJH) method. The adsorbate suitable for evaluation of porosity of pineapple leaf waste was nitrogen at $77 \mathrm{~K}$ using Quantachrome Autosorb Automated Gas Sorption System apparatus. The $0.2 \mathrm{~mm}$ particle sized pineapple leaf waste sample was degassed for overnight at $60{ }^{\circ} \mathrm{C}$ to remove the moisture from the pores.

\section{Results and discussion}

\section{Biochemical characterization of pineapple leaf waste}

Biochemical characterisation of pineapple leaf waste clearly indicate that it was rich in cellulose $(42.29 \% \pm 0.32, \mathrm{w} / \mathrm{w})$ and hemicellulose $(25.18 \% \pm 0.25$, $\mathrm{w} / \mathrm{w})$ with significant lignin $(13.05 \% \pm 0.33 \mathrm{w} / \mathrm{w})$ content. The reported composition of cellulose $(43.53 \% \pm 1.17$, $\mathrm{w} / \mathrm{w})$, hemicellulose $(21.88 \% \pm 0.22, \mathrm{w} / \mathrm{w})$ and lignin $(13.88 \% \pm 1.70, \mathrm{w} / \mathrm{w})$ of pineapple leaf were in close proximity with that obtained in the present study [23]. For efficient utilization of holocelluloses for biofuel production, the lignin barrier should be distorted by laccase mediated delignification process.

\section{Elemental analysis of pineapple leaf waste}

The elemental analysis (Table 2) depicts a slight decrease in CHNS content in the delignified substrate in comparison with the raw substrate. During laccase mediated delignification, the breakdown of $\mathrm{C}=\mathrm{C}, \mathrm{C}-\mathrm{H}$ bonds in lignin and $\mathrm{C}=\mathrm{O}$ bonds in hemicellulose and lignin were observed (FTIR analysis), which might be the plausible reason for the decrease. The reduction in the carbon content of the delignified pineapple leaf waste was estimated to be around $1.8 \%(\mathrm{w} / \mathrm{w})$. The diminutive decrease in the carbon content during the process proves the effectiveness of the enzymatic delignification for better fuel properties of the substrate.

\section{Parameters affecting enzymatic delignification process}

A range of various parameters were considered for studying their effect on delignification of pineapple leaf waste. The percentage delignification and its corresponding residual lignin for all the parameters were shown in the Fig. 1. It was found that solid loading $20 \%(w / v)$, incubation time $6 \mathrm{~h}, 40{ }^{\circ} \mathrm{C}, \mathrm{pH} 7$ and enzyme concentration $500 \mathrm{IU} / \mathrm{mL}$ showed maximum percentage delignification.

\section{Optimization of enzymatic delignification of pineapple leaf waste}

Using the experimental data of enzymatic delignification and various interaction terms of experimental variables, a second order polynomial equation was fitted for the process which is represented as:

$$
\begin{aligned}
\text { Delignification }(\%)= & -337.974-6.487 \times \text { solid loading }+38.983 \times \text { incubation time } \\
& +9.811 \times \text { temperature }+31.764 \times \mathrm{pH}+0.120 \times \text { enzyme concentration } \\
& +0.147 \times \text { solid loading } \times \text { solid loading }-4.064 \times \text { incubation time } \times \text { incubation time } \\
& -0.070 \times \text { temperature } \times \text { temperature }-1.294 \times \mathrm{pH} \times \mathrm{pH} \\
& -0.001 \times \text { enzyme concentration } \times \text { enzyme concentration } \\
& +0.270 \times \text { solid loading } \times \text { incubation time }-0.059 \times \text { solid loading } \times \text { temperature } \\
& +0.096 \times \text { solid loading } \times \mathrm{pH}+0.002 \times \text { solid loading } \times \text { enzyme concentration } \\
& +0.107 \times \text { incubation time } \times \text { temperature }-0.281 \times \text { incubation time } \\
& \times \mathrm{pH}+0.005 \times \text { incubation time } \times \text { enzyme concentration } \\
& -0.346 \times \text { temperature } \times \mathrm{pH}-0.001 \times \text { temperature } \times \text { enzyme concentration } \\
& -0.002 \times \mathrm{pH} \times \text { enzyme concentration. }
\end{aligned}
$$


In the above equation, units for solid loading, incubation time, temperature and enzyme concentration are \% $(\mathrm{w} / \mathrm{v}), \mathrm{h},{ }^{\circ} \mathrm{C}$ and $\mathrm{IU} / \mathrm{mL}$ respectively. Analysis of variance (ANOVA) of the quadratic equation for the delignification (\%) of pineapple leaf waste has been summarized in Table 3 . The regression model for enzymatic delignification of pineapple leaf waste showed a considerable high $F$ value $(27.23)$ and very low $P$ value $(<0.001)$ thus specifying the significance of the model. High $\mathrm{R}^{2}$ value $(0.96)$ of laccase delignified pineapple leaf waste demonstrates the robustness of the model. No significant difference between the $R^{2}$ and adjusted $R^{2}$ values was observed, indicating that the regression model is reliable and competent for the process. It is noted from the coefficients of terms in the regression equation that the individual terms of incubation time, $\mathrm{pH}$, temperature and square terms of $\mathrm{pH}$ have profound influence on the percentage of delignification.

The 3D response surface plots are graphical representation of the regression equation. The response surface plots pertaining to the conditions for enzymatic delignification of pineapple leaf waste were shown in Fig. 2. Each plot in the figure represents the effect of two variables on the percentage delignification. The interaction between incubation time and $\mathrm{pH}$, enzyme concentration and $\mathrm{pH}$, incubation time and enzyme concentration, incubation time and temperature on delignification (\%) were shown in the Fig. $2 \mathrm{a}-\mathrm{d}$ respectively.

Figure $2 \mathrm{a}$ depicts that with an increase in incubation time and $\mathrm{pH}$ the percentage delignification increases up to an optimum incubation time $(6 \mathrm{~h})$ and $\mathrm{pH}(7)$. Thereafter, a slight decrease was observed which may be due to the loss of enzyme stability at high $\mathrm{pH}$ and prolonged incubation time. From the Fig. 2b, c it was observed that percentage delignification increased up to optimum enzyme concentration (500 IU/mL), incubation time $(6 \mathrm{~h})$ and $\mathrm{pH}(7)$. After that, slight decrease in delignification percentage was observed which may be due to saturation of the catalytic sites of the enzyme or loss of stability of enzyme. Figure $2 d$ illustrates that maximum delignification was obtained at interaction between upper limit of temperature $\left(45^{\circ} \mathrm{C}\right)$ and middle level of incubation time $(6 \mathrm{~h})$. This possibly signifies negligible thermal degradation of enzyme up to the maximum temperature level.

$\begin{aligned} & \text { Table } 2 \text { Elemental analysis } \\
& \text { pineapple leaf waste }\end{aligned}$
\begin{tabular}{lllllll}
\hline Substrate & C (wt\%) & H (wt\%) & N (wt\%) & S (wt\%) & O (wt\%) \\
\hline Raw & 39.16 & 4.77 & 1.97 & 0.17 & 53.93 \\
Pretreated & 37.37 & 4.65 & 1.54 & 0.13 & 56.31 \\
\hline
\end{tabular}

Oxygen (wt\%) was calculated by difference
From the analysis of response surface plots, the optimum conditions for enzymatic delignification were found to be solid loading $25 \%(\mathrm{w} / \mathrm{v})$, incubation time $5.30 \mathrm{~h}$, $45{ }^{\circ} \mathrm{C}, \mathrm{pH}$ 6.16, enzyme concentration 582.82 (IU/mL). Under these optimum conditions, the predicted delignification was $77.56 \%$ which was close to the experimental delignification $78.57 \%$. Similar results were reported in Bambusa bambos where the maximum delignification of $84 \%$ was obtained at $\mathrm{pH} 6.9,35{ }^{\circ} \mathrm{C}$, liquid:solid ratio $6: 1$, incubation time $8 \mathrm{~h}$, and enzyme concentration $400 \mathrm{IU} /$ $\mathrm{mL}$ [14]. It is not essential to degrade the entire lignin content of lignocellulosics to obtain a significant increase in digestibility, rather $20-65 \%$ of the lignin degradation can significantly improve the yield of enzymatic hydrolysis depending on the source of cellulose [24]. Through RSM based on CCD, maximum delignification of pineapple leaf waste was obtained at high solid loading and short incubation time, which makes the process viable.

\section{Energy density measurement}

Energy density plays a very important role not only in determining the efficacy of lignocellulosic feedstock as a potential biofuel producer but also for validating the efficiency of the process involved in the biofuel generation viz. the delignification process. A low energy density feed stock is less energy efficient to convert into biofuel than that of high energy density feedstock. The energy density of the raw and enzymatically delignified pineapple leaf waste was found to be $17.13 \pm 0.65 \mathrm{~kJ} / \mathrm{g}$ and $15.95 \pm 0.5 \mathrm{~kJ} / \mathrm{g}$ respectively. The reduction in the energy density of delignified pineapple leaf waste compared to the raw substrate may be due to lignin degradation which is in accordance with the reported work where energy density of the lignocellulosic feedstock (Kans grass) was reduced after enzymatic delignification process [25]. There exists a direct relationship between the lignin content and the higher heating value (HHV) of the biomass. The heating value of lignin is comparatively high than that of cellulose as the degree of oxidation is higher for lignin [26].

\section{Structural characterization of delignified pineapple leaf waste}

The changes in structure of pineapple leaf waste after enzymatic delignification under optimum conditions from RSM were assessed through SEM studies. The delignification process creates cracks and pores on the substrate due to the removal of lignin which was clearly observed in the SEM images of raw and delignified biomass (Fig. 3). The delignification process makes the lignocellulosic substrate more susceptible to saccharification by exposing the cellulosic material to cellulase and thereby enhances the yield of fermentable sugars. 

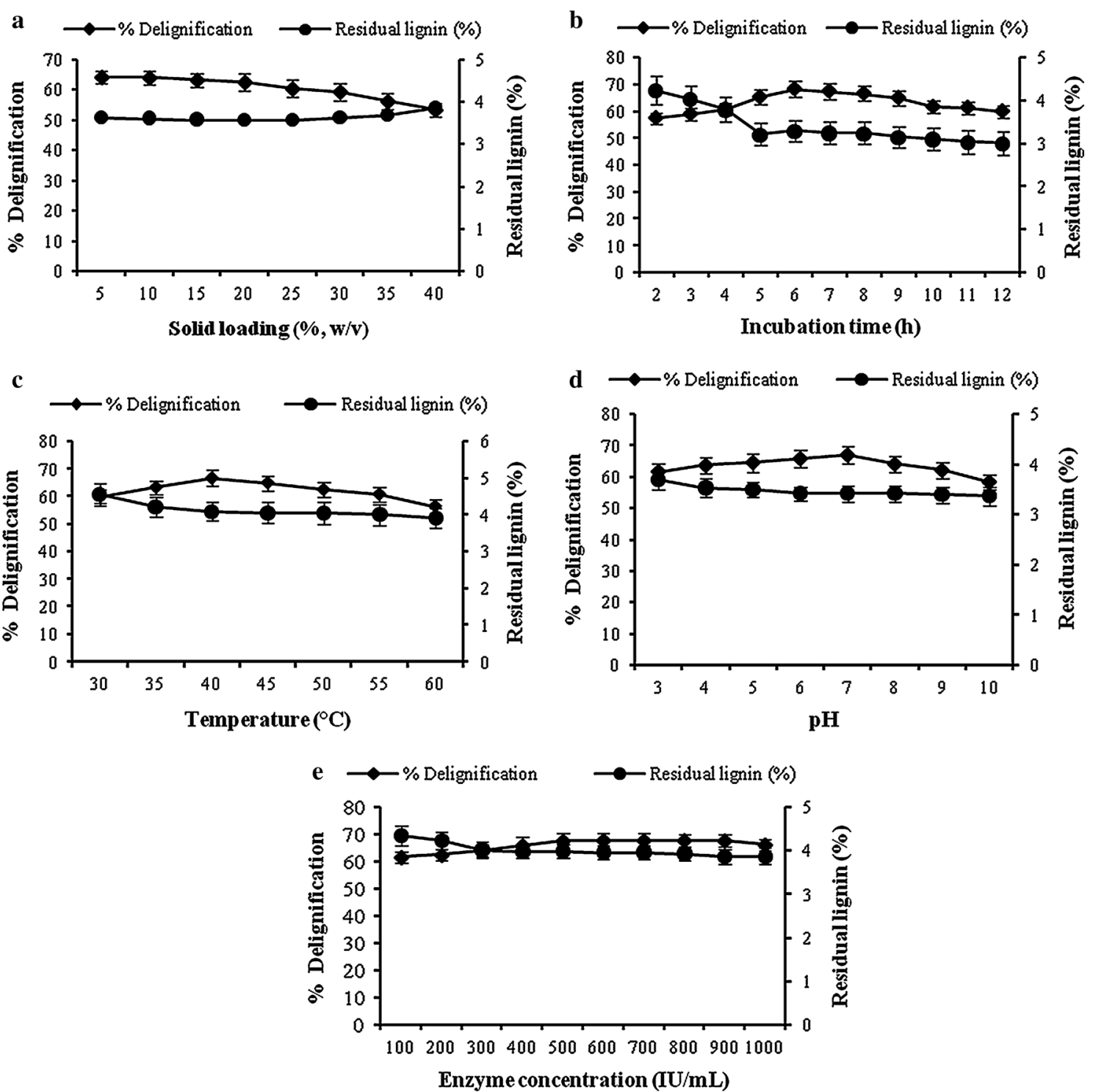

Fig. 1 Effect of a solid loading $\mathbf{b}$ incubation time $\mathbf{c}$ temperature $\mathbf{d} \mathrm{pH}$ e enzyme concentration on percentage delignification and residual lignin. Raw pineapple leaf waste powder is the substrate and effect of various parameters like solid loading (5-40\% w/v), incubation time (2-12 h), temperature $\left(30-60^{\circ} \mathrm{C}\right), \mathrm{pH}(3-10)$ and enzyme concentration $(100-1000 \mathrm{IU} / \mathrm{mL})$ on enzymatic delignification process of the substrate has been studied

FTIR has been used to explore the changes of the functional groups and compositional modifications in laccase delignified substrate against the raw substrate with significant changes in the absorption spectrum of delignified substrate (Fig. 4). Notable decrease in the absorption peaks was observed at $3396 \mathrm{~cm}^{-1}$ (OH stretching of lignin), $2919 \mathrm{~cm}^{-1}$ (C-H stretching of lignin), $1735 \mathrm{~cm}^{-1}$ ( $\mathrm{C}=\mathrm{O}$ stretching of hemicellulose), $1629 \mathrm{~cm}^{-1}(\mathrm{C}=\mathrm{O}$ stretching vibration in conjugated carbonyl of lignin), $1538 \mathrm{~cm}^{-1}$ and $1515 \mathrm{~cm}^{-1}(\mathrm{C}=\mathrm{C}$ stretching vibrations of aromatic rings of lignin), $1454 \mathrm{~cm}^{-1}$ (aliphatic part of lignin), $1430 \mathrm{~cm}^{-1}$ (C-H in-plane deformation of lignin), $1376 \mathrm{~cm}^{-1}$ (aliphatic $\mathrm{C}-\mathrm{H}$ stretching in methyl and phenol alcohol) $1251 \mathrm{~cm}^{-1}$ (syringyl ring breathing and $\mathrm{C}-\mathrm{O}$ stretching in lignin and xylan), $1050-1150 \mathrm{~cm}^{-1}(\mathrm{C}-\mathrm{OH}$ stretching vibration of the cellulose and hemicelluloses), $1037 \mathrm{~cm}^{-1}(\mathrm{C}-\mathrm{O}, \mathrm{C}=\mathrm{C}$ and $\mathrm{C}-\mathrm{C}-\mathrm{O}$ stretching $)$ and $665 \mathrm{~cm}^{-1}$ (aromatic $\mathrm{C}-\mathrm{H}$ bending of lignin) after enzymatic delignification process [27-29]. The prime reason for the decrease in these absorption peaks is the cleavage of the lignin side chains by laccase without much structural alterations of cellulose and hemicellulose [30]. 
Table 3 ANOVA analysis of RSM model for enzymatic delignification of pineapple leaf waste

\begin{tabular}{|c|c|c|c|c|c|c|}
\hline Source & $\mathrm{DF}^{\mathrm{a}}$ & Seq $\mathrm{SS}^{\mathbf{b}}$ & Adj SS ${ }^{b}$ & Adj MS ${ }^{c}$ & $F$ & $P$ \\
\hline Regression & 20 & 1142.52 & 1142.52 & 57.126 & 14.95 & $<0.001$ \\
\hline Linear & 5 & 427.90 & 152.03 & 30.406 & 7.96 & 0.002 \\
\hline Square & 5 & 520.36 & 520.36 & 104.072 & 27.23 & $<0.001$ \\
\hline Interaction & 10 & 194.26 & 194.26 & 19.426 & 5.08 & 0.006 \\
\hline Residual error & 11 & 42.04 & 42.04 & 3.822 & & \\
\hline Lack-of-fit & 6 & 35.83 & 35.83 & 5.972 & 4.81 & 0.053 \\
\hline Pure error & 5 & 6.21 & 6.21 & 1.242 & & \\
\hline Total & 31 & 1184.56 & & & & \\
\hline
\end{tabular}

$\mathrm{R}^{2}=96.45 \%$

$R^{2}(\operatorname{adj})=90.00 \%$

a Degrees of Freedom

b Sum of Squares

c Mean Square

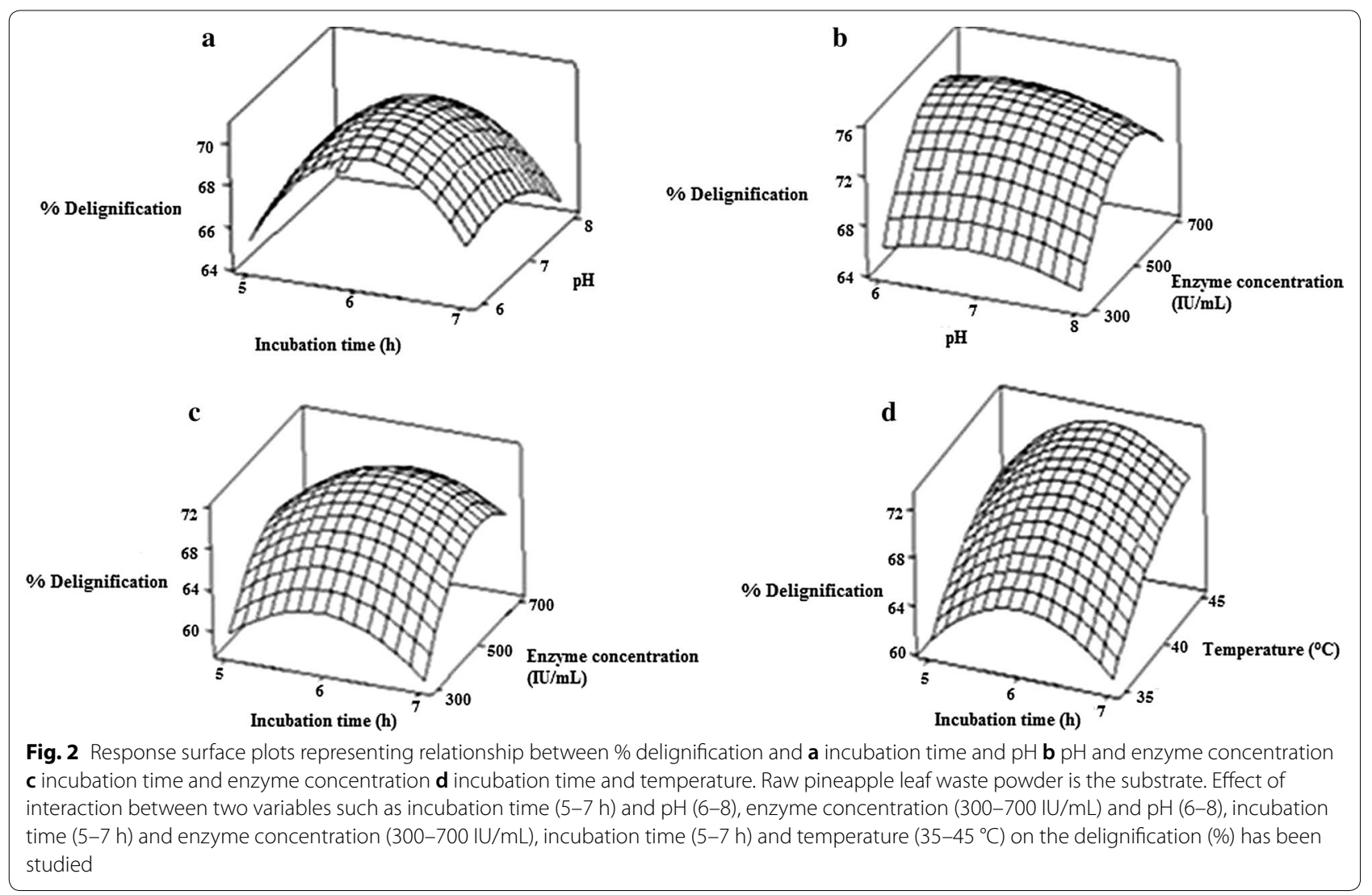

The cellulose accessibility to cellulase for efficient saccharification is governed by various factors like cellulose crystallinity, lignin and hemicellulose content, its distribution in the substrate and porosity [31]. XRD provides an accurate measure of the crystallinity of cellulose. It was observed (Fig. 5) that cellulose crystallinity of raw and delignified substrates were $27.50 \%$ and $33.96 \%$ respectively indicating an increase in relative crystallinity by $6.46 \%$ which may be due to the removal of lignin from pretreated substrate [32]. These results are similar to those obtained in case of Lantana camara where an increase in crystallinity of enzymatically delignified sample (25.21\%) was observed over that of the raw sample (19.57\%) [32]. 
a

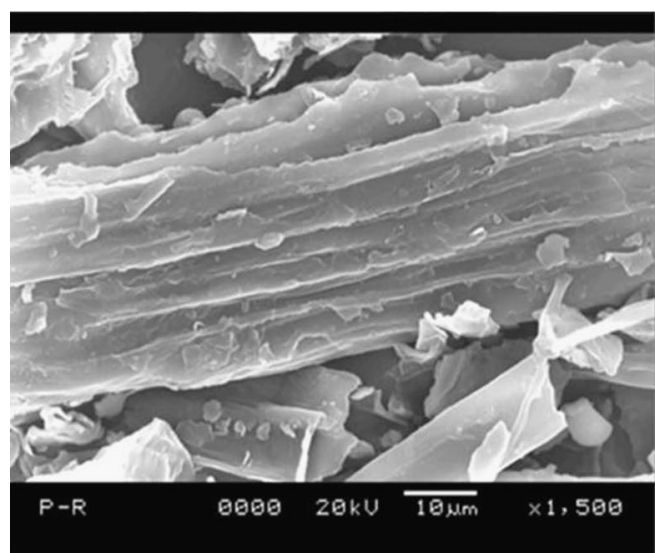

b

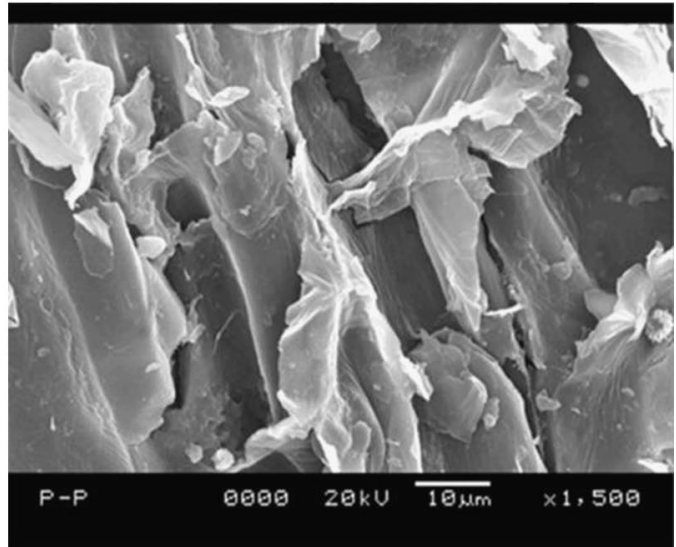

Fig. 3 Scanning electron microscopy images of $\mathbf{a}$ raw and $\mathbf{b}$ delignified pineapple leaf waste. Maximum delignification of pineapple leaf waste has been obtained at solid loading $25 \%(\mathrm{w} / \mathrm{v})$, incubation time $5.30 \mathrm{~h}, 45^{\circ} \mathrm{C}, \mathrm{pH} 6.16$ and enzyme concentration 582.82 (IU/mL). The structural morphology of raw and delignified substrate has been studied

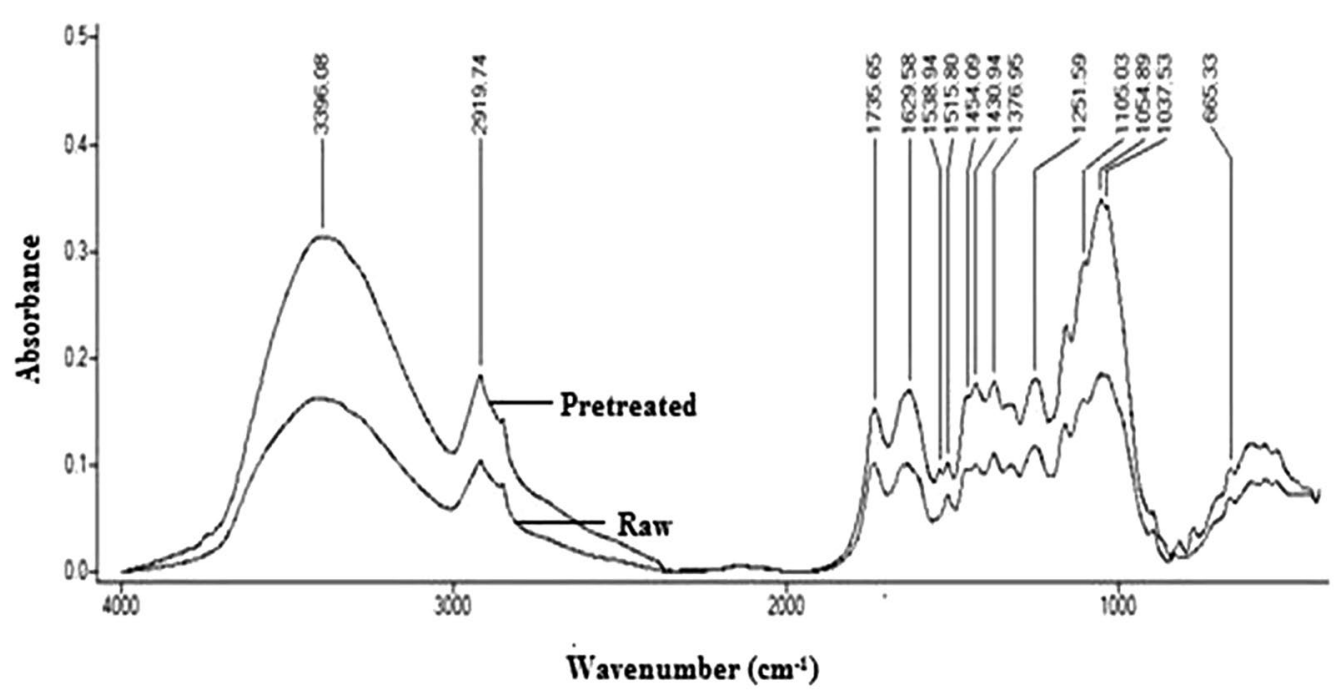

Fig. 4 Fourier transform infrared spectra of raw and delignified pineapple leaf waste. Maximum delignification of pineapple leaf waste has been obtained at solid loading $25 \%(\mathrm{w} / \mathrm{v})$, incubation time $5.30 \mathrm{~h}, 45^{\circ} \mathrm{C}, \mathrm{pH} 6.16$ and enzyme concentration 582.82 (IU/mL). Changes of the functional groups and compositional modifications in laccase delignified substrate against the raw substrate have been studied

The cellulose, hemicellulose and lignin contents of raw and delignified pineapple leaf waste under optimized conditions are provided in Table 4. A significant decrease in lignin (4.66-fold) and hemicellulose content (1.31-fold) was observed from delignified substrate as compared to the raw substrate. The cellulose obtained from pineapple leaf waste after delignification process is nearly 1.09-folds higher than that obtained from the raw pineapple leaf waste. These biochemical changes illustrate the action of laccase on pineapple leaf waste.
To determine the effect of delignification on production of reducing sugar, saccharification was performed with raw and delignified pineapple leaf waste. The reducing sugar $(\mathrm{mg} / \mathrm{g})$ from raw and delignified substrates was found to be $189.0 \pm 8.89$ and $492.33 \pm 3.1$ respectively with a significant increase of 2.6 -folds. The results show that enzymatically delignified pineapple leaf waste can produce considerably high amount of reducing sugar after saccharification. 


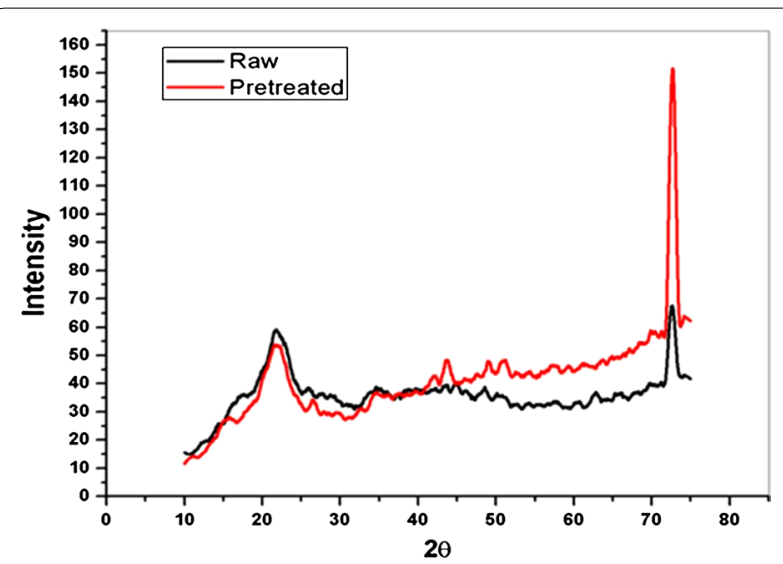

Fig. 5 X-ray diffraction spectra of raw and delignified pineapple leaf waste. Maximum delignification of pineapple leaf waste has been obtained at solid loading $25 \%(\mathrm{w} / \mathrm{v})$, incubation time $5.30 \mathrm{~h}, 45^{\circ} \mathrm{C}, \mathrm{pH}$ 6.16 and enzyme concentration $582.82(\mathrm{IU} / \mathrm{mL})$. Change in cellulose crystallinity of laccase delignified substrate has been studied against the raw substrate

Table 4 Biochemical composition of raw and delignified pineapple leaf waste

\begin{tabular}{llr}
\hline Component & Initial & \multicolumn{1}{c}{$@ 5.30 \mathbf{h}$} \\
\hline Lignin (\%, w/w) & $13.05 \pm 0.33$ & $2.78 \pm 0.25$ \\
Cellulose (\%, w/w) & $42.29 \pm 0.32$ & $45.20 \pm 0.98$ \\
Hemicellulose (\%, w/w) & $25.18 \pm 0.25$ & $19.80 \pm 0.73$ \\
\hline
\end{tabular}

Table 5 Changes in surface area, pore volume and pore diameter of pineapple leaf waste before and after enzymatic delignification

\begin{tabular}{llll}
\hline Sample & $\begin{array}{l}\text { Surface area } \\
\left(\mathbf{m}^{\mathbf{2}} \mathbf{g}\right)\end{array}$ & Pore volume $(\mathbf{c c} / \mathbf{g})$ & $\begin{array}{l}\text { Pore } \\
\text { diameter } \\
\mathbf{( n m})\end{array}$ \\
\hline Raw & 1.41 & $4.26 \times 10^{-3}$ & 12.00 \\
Delignified & 2.51 & $5.51 \times 10^{-3}$ & 13.95 \\
\hline
\end{tabular}

\section{Measurement of specific surface area, pore size and pore} volume of raw and delignified substrate

One of the important parameters that affect the hydrolysis rate of cellulose is specific surface area. The absorption of cellulase on the surface of cellulose is mandatory for the hydrolysis reaction to occur as the extent of hydrolysis depends on the surface area accessible to the enzymes. Based on BET analysis (Table 5), surface area of raw and delignified pineapple leaf waste under optimized conditions were found to be 1.41 and $2.51 \mathrm{~m}^{2} / \mathrm{g}$ respectively, that showed an increase in the surface area by 1.78 -folds. The obtained results from the present study are substantially higher than the reported work where surface area analysis of raw and ionic liquid pretreated oil palm empty fruit bunch was $0.55 \mathrm{~m}^{2} / \mathrm{g}$ and $0.75 \mathrm{~m}^{2} / \mathrm{g}$ [33]. BJH analysis was carried out to determine the pore size and its volume through $\mathrm{N}_{2}$ adsorption and desorption techniques.

There exist a direct relation between the pore volume or interior surface area of the substrate and the extent of hydrolysis by cellulase [34]. Enhanced cellulose hydrolysis was observed when the pores of the substrate were large enough to accommodate adequate cellulase [35]. The rate-limiting pore size for the hydrolysis of lignocellulosic substrates was reported to be $5.1 \mathrm{~nm}$ [36]. The pore size (diameter) of raw and delignified pineapple leaf waste from $\mathrm{BJH}$ analysis was found to be $12.00 \mathrm{~nm}$ and $13.95 \mathrm{~nm}$ respectively which suggests the pineapple leaf waste to be mesoporous in nature. Laccase delignified pineapple leaf waste with increased pore volume (by nearly 1.3 -folds, Table 5) can improve the production of reducing sugar.

The prime objective of the delignification process is to remove lignin that acts as barrier to cellulose which is major contributor of reducing sugar. Conventional pretreatment process not only leads to a significant amount of hemicellulose loss along with lignin but also results in formation of intermediates such as furfurals and hydroxymethylfurfurals that may act as inhibitors for the fermentation process. Besides, conventional pretreatment processes are also associated with equipment corrosion, high cost, high water requirement, excess use of chemicals, formation and incorporation of salts into the biomass and enormous waste production. In order to overcome these issues, enzymatic delignification of biomass was carried out in the present study. Enzymatic delignification is an eco-friendly process which can work under mild operating conditions. Laccase being specific, acts on lignin moieties of the substrate and has less effect on the structure and composition of cellulose and hemicelluloses. Laccase mediated delignification enhances saccharification efficiency of cellulase thereby leading towards cleaner production of biofuel [37] such as biobutanol, bioethanol and bio-chemicals like lactic acid, acetic acid, sorbitol, xylitol, vanillin etc.

\section{Conclusion}

Biochemical characterisation of pineapple leaf waste shows the presence of high cellulose and hemicellulose with significant lignin content. Laccase mediated delignification process degrades lignin up to $78.57 \%(\mathrm{w} / \mathrm{w})$ which is accompanied by an increase in cellulose crystallinity of $6.46 \%$. This substantiates the effective action of laccase on pineapple leaf waste during delignification process which results in increased production of reducing sugar $(492.33 \pm 3.1 \mathrm{mg} / \mathrm{g})$. Structural characterization as well as surface area and porosity analysis of the 
substrate further corroborate the enzymatic delignification process. The energy density studies of pineapple leaf waste prove that it is a competent substrate for biofuel production. In the perspective of cleaner production, enzymatic delignification of biomass is a green, sustainable and eco-friendly process for improved production of reducing sugar that contributes for efficient biofuel production. The agro-industrial waste utilization for generation of value added products is not only an effective way of waste removal from the environment but also economical.

\footnotetext{
Abbreviations

RSM: response surface methodology; CCD: central composite design; FTIR: Fourier transformed infrared spectroscopy; XRD: X-ray diffraction; SEM: scanning electron microscopy; Mt: million tonnes; Mha: million hectares; ABTS: 2,2'-azino-bis (3-ethylbenzothiazoline-6-sulphonic acid; IU: international units; $\mathrm{kJ} / \mathrm{g}$ : kilojoules per gram; $\mathrm{nm}$ : nanometre; cc/g: cubic centimetre per gram; $\mathrm{mg} / \mathrm{g}$ : milligram per gram.
}

\section{Authors' contributions}

RB have conceived the idea of enzymatic delignification of lignocellulosic biomass and guided the work carried out in the present article. ADC has performed the experimental work and authorized the article under the guidance of RB. RB and SR have edited the manuscript meticulously. All authors read and approved the final manuscript.

\section{Author details}

${ }^{1}$ Agricultural \& Food Engineering Department, Indian Institute of Technology, Kharagpur, West Bengal 721302, India. ${ }^{2}$ Advanced Technology Development Centre, Indian Institute of Technology, Kharagpur, West Bengal 721302, India. ${ }^{3}$ Chemical Engineering Department, Indian Institute of Technology, Kharagpur, West Bengal 721302, India.

\section{Acknowledgements}

Not applicable.

\section{Competing interests}

The authors declare that they have no competing interests.

\section{Availability of data and materials}

The dataset used and/or analyzed during the current study are available from the corresponding author on reasonable request.

\section{Funding}

Authors acknowledge Department of Biotechnology (DBT), New Delhi for financial assistance to carry out this work. The Grant Number is BT/PR15280/ AGR/26/255/2011. This study was funded by Waiver agreed for a submission to the new section of CCJ (waiver code CCJ-COMP agreed with Samuel Winthrop, Senior JDE).

\section{Publisher's Note}

Springer Nature remains neutral with regard to jurisdictional claims in published maps and institutional affiliations.

Received: 23 March 2017 Accepted: 11 April 2019

Published online: 23 April 2019

\section{References}

1. Zahari MAKM, Abdullah SSS, Roslan AM, Ariffin H, Shirai Y, Hassan MA (2014) Efficient utilization of oil palm frond for bio-based products and biorefinery. J Clean Prod 65:252-260
2. Porzi GF, Prussi M, Chiaramonti D, Pari L (2012) Modelling lignocellulosic bioethanol from poplar: estimation of the level of process integration, yield and potential for co-products. J Clean Prod 34:66-75

3. Yang Y, Sharma-Shivappa R, Burns JC, Cheng JJ (2009) Dilute acid pretreatment of oven-dried switchgrass germplasms for bioethanol production. Energy Fuels 23:3759-3766

4. Panagiotopoulos IA, Lignos GD, Bakker RR, Koukios EG (2012) Effect of low severity dilute-acid pretreatment of barley straw and decreased enzyme loading hydrolysis on the production of fermentable substrates and the release of inhibitory compounds. J Clean Prod 32:45-51

5. FAOSTAT (2015) http://faostat3.fao.org/browse/Q/*/E. Accessed 20 Feb 2016

6. Indian Horticulture Database (2014) National Horticulture Board, Ministry of Agriculture, Govt. of India 249

7. Roda A, Faver DMD, Dordoni R, Lambri M (2016) Effect of pre-treatments on the saccharification of pineapple waste as a potential source for vinegar production. J Clean Prod 112:4477-4484

8. Samuel R, Foston M, Jaing N, Cao S, Allison L, Studer M (2011) HSQC (heteronuclear single quantum coherence) $13 \mathrm{C}-1 \mathrm{H}$ correlation spectra of whole biomass in perdeuterated pyridinium chloride-DMSO system: an effective tool for evaluating pretreatment. Fuel 90:2836-2842

9. Camarero S, Ibarra D, Martínez MJ, Martínez AT (2005) Lignin-derived compounds as efficient laccase mediators for decolorization of different types of recalcitrant dyes. Appl Environ Microbiol 71:1775-1784

10. Kataria R, Ruhal R, Babu R, Ghosh S (2013) Saccharification of alkali treated biomass of Kans grass contributes higher sugar in contrast to acid treated biomass. Chem Eng J 230:36-47

11. Ranjan A, Moholkar VS (2013) Comparative study of various pretreatment techniques for rice straw saccharification for the production of alcoholic biofuels. Fuel 112:567-571

12. Heap L, Green A, Brown D, Dongenc BV, Turner N (2014) Role of laccase as an enzymatic pretreatment method to improve lignocellulosic saccharification. Catal Sci Technol 4:2251-2259

13. Claus H (2004) Laccases: structure, reactions, distribution. Micron 35:93-96

14. Kuila A, Mukhopadhyay M, Tuli DK, Banerjee R (2011) Accessibility of enzymatically delignified bambusa bambos for efficient hydrolysis at minimum cellulase loading: an optimization study. Enzyme Res 2011:1-8

15. Rico A, Rencoret J, del Río JC, Martínez AT, Gutiérrez A (2014) Pretreatment with laccase and a phenolic mediator degrades lignin and enhances saccharification of Eucalyptus feedstock. Biotechnol Biofuels 7:6

16. Bingol D, Kulcu M (2011) Optimization of the solid phase extraction method for determination of $\mathrm{Cu}(I)$ in natural waters by using response surface methodology. Analyst 136:4036-4044

17. Hussain MA, Huq ME, Rahman SM (2002) Estimation of lignin in jute by titration method. Pak J Biol Sci 5:521-522

18. Viles FJ, Silverman L (1949) Determination of starch and cellulose with anthrone. Anal Chem 21:950-953

19. Marlett JA, Lee SC (2006) Dietary fiber, lignocellulose and hemicellulose contents of selected foods determined by modified and unmodified van soest procedures. J Food Sci 45:1688-1693

20. Miller GL (1959) Use of dinitrosalicylic acid reagent for determination of reducing sugar. Anal Chem 31:426-428

21. Bhattacharya SS, Banerjee R (2008) Laccase mediated biodegradation of 2,4 dichlorophenol using response surface methodology. Chemosphere 73:83-85

22. Segal L, Creely JJ, Martin AE, Conrad CM (1959) An empirical methods for estimating the degree of crystallinity of native cellulose using the X-ray diffraction. Textile Res J 29:786-794

23. Cassellis MER, Pardo MES, Lopez MR, Escobedo RM (2014) Structural, physico-chemical and functional properties of industrial residues of pineapple (Ananas comosus). Cellulose Chem Technol 48:633-641

24. Fan LT, Gharpuray MM, Lee YH (1987) Cellulose hydrolysis. Springer, Hamburg

25. Rajak RC, Banerjee R (2015) Enzymatic delignification: an attempt for lignin degradation from lignocellulosic feedstock. RSC Adv 5:75281-77591

26. Demirbas A (2003) Relationships between heating value and lignin, fixed carbon, and volatile material contents of shells from biomass products. Energy Source 25:629-635 
27. Ghali AE, Marzoug IB, Baouab MHV, Roudesli MS (2012) Separation and characterization of new cellulosic fibres from the Juncus acutus plant. Bioresour Technol 7:2002-2018

28. Ding TY, Hii SL, Ong LGA (2012) Comparison of pretreatment strategies for conversion of coconut husk fiber to fermentable sugars. Bioresour Technol 7:1540-1547

29. Shi J, Li J (2012) Metabolites and chemical group changes in the wood forming tissue of Pinus koraiensis under inclined condition. Bioresour Technol 7:3465-3475

30. Sun Q, Foston M, Meng X, Sawada D, Pingali SV, Neill HMO, Li H, Wyman CE, Langan P, Ragauskas AJ, Kumar R (2014) Effect of lignin content on changes occurring in poplar cellulose ultrastructure during dilute acid pretreatment. Biotechnol Biofuels 7:150

31. Park S, Baker JO, Himmel ME, Parilla PA, Johnson DK (2010) Cellulose crystallinity index: measurement techniques and their impact on interpreting cellulase performance. Biotechnol Biofuels 3:10

32. Kuila A, Mukhopadhyay M, Tuli DK, Banerjee R (2011) Production of ethanol from lignocellulosics: an enzymatic venture. EXCLI J 10:85-96
33. Katinonkul W, Lee JS, Ha SH, Park JY (2012) Enhancement of enzymatic digestibility of oil palm empty fruit bunch by ionic-liquid pretreatment. Energy 47:11-16

34. Shevchenko SM, Chang K, Robinson J, Saddler JN (2000) Optimization of monosaccharide recovery by post-hydrolysis of the water-soluble hemicellulose component after steam explosion of softwood chips. Bioresour Technol 72:207

35. Tanaka M, Ikesaka M, Matsuno R (1988) Effect of pore size in substrtae and diffusion of enzyme on hydrolysis of cellulosic materials with cellulase. Biotechnol Bioeng 32:698-706

36. Wong KY, Deverell KF, Mackie KL, Clark TA, Donaldson LA (1988) The relationship between fibre porosity and cellulose digestibility in steamexploded Pinus radiata. Biotechnol Bioeng 31:447-456

37. Jegannathan KR, Nielsen PH (2013) Environmental assessment of enzyme use in industrial production - a literature review. J Clean Prod 42:228-240
Ready to submit your research? Choose BMC and benefit from:

- fast, convenient online submission

- thorough peer review by experienced researchers in your field

- rapid publication on acceptance

- support for research data, including large and complex data types

- gold Open Access which fosters wider collaboration and increased citations

- maximum visibility for your research: over $100 \mathrm{M}$ website views per year

At BMC, research is always in progress.

Learn more biomedcentral.com/submissions 